\title{
Alleviation of Diabetes-Induced Hepatotoxicity by Date Palm Hydroalcoholic Extract in Rat Model; A Biochemical, Immunohistochemical and Stereological Study
}

\author{
Alivio de la Hepatotoxicidad Inducida por Diabetes Mediante el Extracto Hidroalcohólico de Palmera \\ Datilera en Modelo de Rata: Un Estudio Bioquímico, Inmunohistoquímico y Estereológico
}

\author{
Yun Zheng ${ }^{1}$; Attalla F. El-kott ${ }^{2,3}$; Fayez Shaldoum ${ }^{4,5}$; Diaa Massoud ${ }^{6,7}$; ${\text { Yan } \text { Pan }^{8} \text { \& Eman R. ElBealy }}^{9}$
}

ZHENG, Y.; EL-KOTT, A. F.; SHALDOUM, F.; MASSOUD, D.; PAN, Y. \& ELBEALY, E. R. Alleviation of diabetes-induced hepatotoxicity by date palm hydroalcoholic extract in rat model; A biochemical, immunohistochemical and stereological study. Int. J. Morphol., 39(3):876-885, 2021.

SUMMARY: The present study was aimed to investigate the hepatoprotective effects of date palm hydroalcoholic extract (DP)in diabetic rats using biochemical and histopathological approaches. Diabetes was induced by administration of $60 \mathrm{mg} / \mathrm{kg}$ of streptozotocin intraperitoneally. In this analysis 32 adult rats were randomly divided into four groups; group 1:non-diabetic control whic received $0.1 \mathrm{~mL}$ normal saline, group 2:served as non-diabetic control which treated with $270 \mathrm{mg} / \mathrm{kg}$ of DP, group 3: served as untreated diabetic, and group 4: diabetic rats treated with $270 \mathrm{mg} / \mathrm{kg}$ of DP. Diabetic rats treated with the DP extracts exhibited lower hepatic oxidative stress and lower hepatic enzymes level. Extract treatment decreased the level of malondealdehyde (MDA) as a marker of lipid peroxidation. Stereological estimations revealed a significant increase in the liver volume in diabetic rats which was reduced in DP-treated rats. Immunofluorescence staining showed high synthesis of acrolein as a byproduct of lipid proxidation. While, optical density measurement revealed significant decrease in acrolein after DP administration. Histopathological examination showed severe changes in untreated diabetic liver tissue manifested by dilated portal vein, leukocytic infiltration, fatty degeneration and necrotic nuclei, whereas, DP treatment attenuated the adverse effects of diabetes on the liver represented by relatively healthy hepatocytes and sinusoids. The obtained results indicated that date pam extract was beneficial in the prevention of diabetes-induced hepatotoxicity due to its natural antioxidant constituents. Further preclinical and clinical studies are needed for considering this plant in management of prediabetes and diabetes hepatic complications.

KEY WORDS: Date palm; Diabetes; Acrolein; Antioxidant; Hepatoprotection.

\section{INTRODUCTION}

Diabetes is a chronic disorder in the metabolism of proteins, fats and carbohydrates and causes an imbalance in the conversion of these compounds into energy. This disease is caused by a defect in the production of the hormone insulin (Kitabchi et al., 2009). In this metabolic disorder, in addition to uncontrollably increasing blood glucose levels, other complications such as hyperosmolar hyperglycemic syndrome, diabetic ketoacidosis (DKA), microvascular complications (diabetic retinopathy, diabetic nephropathy and diabetic neuropathy) and especially liver diseases are seen (Canadian Diabetes Association Clinical Practice Guidelines Expert Committee et al., 2013). In diabetic patients, due to insulin resistance, the liver can't convert glucose into glycogen or release glucose into the bloodstream when needed. This event indicates a challenge in controlling blood glucose level. Therefore, the association of diabetes with chronic liver diseases, cirrhosis, and liver cancer has been proven (Andreoli et al., 2007). Moreover, restrospective studies showed that with non-alcoholic fatty liver disease (NAFLD) increased the risk of diabetes mellitus (DM), and patients with cirrhosis are more prone to the progression of DM (McPherson et al., 2015; Mantovani et al., 2018; Sung et al., 2019). In view of the relationship between DM and liver diseases, proper management of diabetes and DM-

\footnotetext{
${ }^{1}$ Department of Pathology, Baoji Hospital of Traditional Chinese Medicine, Baoji, 721000, China.

${ }^{2}$ Biology Department, Faculty of Science, King Khalid University, Abha 61421, Saudi Arabia.

${ }^{3}$ Zoology Department, College of Science, Damanhour University, Damanhour 22511, Egypt.

${ }^{4}$ Department of Biology, College of Science, Jouf University, Sakaka, Al-Jawf, Saudi Arabia.

${ }^{5}$ Department of Zoology, Faculty of Science, Al-Azhar University, Cairo, Egypt.

${ }^{6}$ Biology Department, College of Science, Jouf University, P.O. Box 2014, Sakaka, Al-Jouf, Saudi Arabia.

${ }^{7}$ Zoology Department, Faculty of Science, Fayoum University, Fayoum, Egypt.

${ }^{8}$ Department of Burn and Plastic Surgery, Xi' an Central Hospital, No 161, Xiwu Road, Xi'an City, Shaanxi Province, 710003, China.

${ }^{9}$ Biology Department, College of Science for girls, King Khalid University, Abha 61421, Saudi Arabia.
} 
related complications is of utmost importance. There is much supporting evidence that oxidative stress is one of the main causes of diabetic complications (Palsamy et al., 2010).

Excessive production free radicals results in several deleterious events, including an irreversible oxidative modification of lipids, proteins and carbohydrates (Parveen et al., 2010; Leung \& Nieto, 2013). In addition, it will induce apoptosis in hepatocytesand the release of inflammatory cytokines, thereby increasing the expression of adhesion molecules and the infiltration of leukocytes. Therefore, a combination of oxidative stress and inflammatory pathways cause massive hepatic injuries (Welt et al., 2004; Wei et al., 2010). On the other hand, hyperglycemia leads to a depletion in antioxidant status of the liver and an increase in reactive oxygen species (ROS) generation which contribute to more oxidation-induced liver damage (Han et al., 2006; Manna et al., 2010; Leung \& Nieto).

In traditional medicine, most herbs due their antioxidant compounds can maintain the function and structure of different types organs such as the liver. Also, in recent years, numerous medicinal plants with hypoglycemic properties are discovered and introduced. As shown in many studies these plants have been associated with changes in the activity hexokinase and glucinase produced by hepatic cells, which reduced blood glucose levels and ultimately improved liver function (Gupta et al., 2004; Lukacínová et al., 2008; Shimoda et al., 2009).

Date palm (Phoenix dactylifera) belongs to the Arecaceae family, consisting of 200 genera and more than 2500 species (Al-Alawi et al., 2017). There is growing evidence regarding anti-inflammatory, anti-fungal, anti-bacterial, immunomodulatory, and anti-tumor effects of date palm (Chaira et al., 2009; Rahmani et al., 2014; Raayati Jahromi et al., 2017). Vayalil) 2002) reported that the concentration of 1.5 and $4 \mathrm{mg} / \mathrm{mL}$ of aqueous date extract can completely inhibited superoxide and hydroxyl radicals, respectively. Its powerful antioxidant activity can be attributed to the phytochemical compound such as phenolic acids, flavonoids, carotenoids as well as phytosterols, phytoestrogens and ferulic acid found within it (Al-Alawi et al.).

The present study was designed to investigate the probable protective effects of Date Palm hydro-alcoholic extract on diabetes-induced hepatotoxicity and oxidative stress. The first-order stereological parameters on liver including the volume and length were estimated using unbiased and designbased stereological procedures, the expression of acrolein protein was evaluated immunohistochemically and antioxidant enzymes in hepatic tissue were assessed to deterime the antioxidant defense status.

\section{MATERIAL AND METHOD}

Extract preparation. After drying the Ashrasi date palm for one week, $200 \mathrm{~g}$ of powdered plant material was placed on $2000 \mathrm{ml}$ ( 1 to $10 \mathrm{wt} / \mathrm{vol}$ ) of $70 \%$ ethanol, the mixture was heated to $40{ }^{\circ} \mathrm{C}$ for 2 hours and cooled simultaneously, Then, it was exposed to ambient temperature for 24 hours. The extract was then straightened by Whatman No. 2 paper. The initial extract was introduced into a vacuum distillation apparatus (rotary vacuum pump) at $80^{\circ} \mathrm{C}$ for one hour.

Animals. Thirty-two adult male rat (weighing 220-260 g, 14 weeks old) were included in the study. The animals were kept under standard conditions ( $12 \mathrm{~h}$ dark $/ 12 \mathrm{~h}$ light cycle, temperature $23 \pm 1{ }^{\circ} \mathrm{C}$ and humidity $50 \% \pm 55 \%$ ) and fed ad libitum.All the protocols were performed under the supervision of the Ethics Committee King Khalid University and were in line with the guidelines of the Animal Ethics Committee (NIH Publication 80-23, 1996).

Diabetes was induced by intraperitoneal injection of a single dose $(60 \mathrm{mg} / \mathrm{kg})$ of streptozotocin (Sigma, St.Louis, MO, USA). 3 days after STZ injection, bloodglucose levels was monitored in 8-hours fasted animals using strip glucometer. The animals with blood glucose higher than 250 $\mathrm{mg} / \mathrm{dl}$ were considered as diabetic and entered the experiment.

\section{Experimental design}

Animals were weighed and randomly divided into four groups each group contained 8 rats $(n=8)$ :

- Group 1: served as control group, received $0.5 \mathrm{ml}$ of normal saline/day orally for 8 weeks.

-Group 2: served as control group received DP hydroalcoholic extract at a dose of $270 \mathrm{mg} / \mathrm{kg}$, orally, for 8 weeks.

- Group 3: served as diabetic group, received $0.5 \mathrm{ml}$ of normal saline /day orally for 8 weeks.

- Group 4: served as diabetic treated group, received DP hydroalcoholic extract at a dose of $270 \mathrm{mg} / \mathrm{kg}$, orally, for 8 weeks (Hosseinipour et al., 2019).

At the end of experiment, the animals were anesthetized using chloroform. Blood samples were collected directly from heart and used for liver enzymes assessment. The whole liver was separated and used for antioxidants and histopathological evaluation.

Liver enzymes measurement. The harvested blood samples were incubated at $37^{\circ} \mathrm{C}$ for 15 min to allow clot formation 
and centrifuged (Hettich, EBA 20, Germany) at 3,000 rpm for 15 minutes to separate the serum. The serum samples were used for measuring hepatic enzymes namely; alkaline phosphatase (ALP) (Cat No: 102395H917), aspartate aminotransferase (AST)(Cat No: 118408H912), and alanine aminotransferase (ALT) (Cat No: 119395H917).

Antioxidant enzymes activities. A small piece (2g) of the liver was sampled and homogenized (Ultra Turrax mechanical blender) in $50 \mathrm{vol}$ of $10 \mathrm{mM}$ potassium phosphate buffer $(\mathrm{pH}=7.4)$ supplemented with $30 \mathrm{mM} \mathrm{KCl}$.

The homogenate was centrifuged at $1300 \mathrm{~g}$ for $15-$ $20 \mathrm{~min}$ at $4{ }^{\circ} \mathrm{C}$ to get enzyme fraction. The obtained supernatant was used for determination of antioxidant enzyme activity and levels of lipid peroxidation (MDA activity). Catalase (CAT) activity was measured according to the UV colorimetric method described by Aebi (1984) at $240 \mathrm{~nm}$ using the oxidizing reaction of nitro blue tetrazolium (NBT) and $\mathrm{H} 2 \mathrm{O} 2$ as substrate (Vijaya Bharathi et al., 2015; Faraji, Momeni, \& Malmir, 2019). Superoxide dismutase (SOD) activity was determined according to the colorimetric method of Martin et al. (1987) at $560 \mathrm{~nm}$. Glutathione peroxidase (GPx) activity was measured according to the method described by Ho et al. (1997) at $340 \mathrm{~nm}$.

The Malondialdehyde (MDA) level was measured by spectrophotometry as per the method of Placer et al. (1966). This method was based on the reaction of MDA with thiobarbituric acid (TBARS), one of the aldehyde products of lipid peroxidation (Placer et al.). BHT was added to the samples for preventing of lipid proxidation during heating the samples (Pakul \& Leszczyns, 1986).

Immunofluorescence of acrolein. Paraffin embedded liver sections were deparaffinized in xylene (three times for 5 mins) and rehydrated with graded ethanol and finally distilled water. Sections then were heated in citrate buffer $(\mathrm{pH}=6)$ within microwave for $5 \mathrm{~min}$. After that sections were washed with PBS buffer for $5 \mathrm{~min}$ and incubated in peroxidase blocking solution for $10 \mathrm{~min}$. Sections were incubated overnight at $4{ }^{\circ} \mathrm{C}$ in primary antibody solution $(1: 200 ;$ mouse anti-acrolein monoclonal antibody;ab240918; Abcam, Cambridge, MA, USA). A FITC-conjugated goat anti-mouse IgG H\&L (ab6785) was used as the secondary antibody $(1: 1000$, Abcam, Cambridge, MA, USA) for $30 \mathrm{~min}$. For nuclear staining, 4',6-diamidino-2-phenylindole (Beyotime Biotech, Nantong, China ) was added for $5 \mathrm{~min}$ and washed three times with PBS. The slides were viewed with a NikonEclipse E600 fluorescence microscope and fluorescence images were acquired. Quantitative analysis of acrolein fluo-rescence intensity was investigated by
Image-Pro Plus (v. 6.0) software (Media Cybernetics, Warrendale, PA, USA). The acrolein fluorescence intensity was calculated by measuring the optical density (OD) in equivalent area $\left(\mathrm{mm}^{2}\right)$. Totally, 20 random images $(\times 20$ magnification) were analyzed for each liver section.

Stereological study. After dissecting the animals, the liver was removed and its total volume was measured according to the Archemides principle (Scherle, 1970). The liver was then fixed in $10 \%$ neutral buffered formalin for one week. After fixation, the samples underwent the orientator method and were cut to obtain isotropic uniform random (IUR) slabs (Nyengaard, 1990). All obtained slabs from each liver were processed in a routine manner and $5 \mu \mathrm{m}$ thick sections were collected (LEICA SM2010RV1.2 microtome, Germany). The sections were stained with hematoxylin and eosin (H\&E) and used for stereological and histopathological assessments.

Volume estimation. A point probe containing 40 point (+) with vertically and horizontally equal distances were used to estimate volume density of desired structures at a final magnification of $\times 400$ (Fig. 1A). Between 10 and 12 microscopic fields were examined in each liver. The point probe was superimposed on the images of the tissue sections and volume density of the hepatocytes, sinusoids, central vein, portal vein, branches of hepatic artery, and bile ducts were estimated using the following formula:

$$
\mathrm{Vv}=\Sigma \mathrm{P}_{\text {structure }} / \Sigma \mathrm{P}_{\text {reference }}
$$

In this fomula ' $\Sigma \mathrm{P}_{\text {structure }}$ ' and ' $\Sigma \mathrm{P}_{\text {reference }}$ ' were the total points hitting the desired structure and reference space in 12 fields of view, respectively. The volume density multiplied by the total volume of the liver to obtain the total volume of each desired structure. Subsequently, the coefficient error (CE) for fractional volume was estimated as follows:

$$
\mathrm{CE}(\mathrm{Vv})=\left[\frac{k}{k-1}\left\{\frac{\sum u^{2}}{\sum u \cdot \sum u}+\frac{\sum v^{2}}{\sum v \cdot \sum v}-2 \frac{\sum u v}{\sum u \cdot \sum v}\right\}\right]^{1 / 2}
$$

In which, $\mathrm{k}$ was the number of sections, $\Sigma u$ was the total points hitting the reference space and $\Sigma v$ was the sum of points hitting the desired structure (Howard \& Reed, 2005).

\section{Length estimation}

The length density of the central vein, portal vein, branches of the hepatic artery and bile ducts was estimated using a counting probe $(560 \times 560)$ and the following formula (Fig. 1B):

$$
L_{v}:=2 \times \frac{\sum Q}{a(\text { frame }) \times \sum \text { frame }}
$$



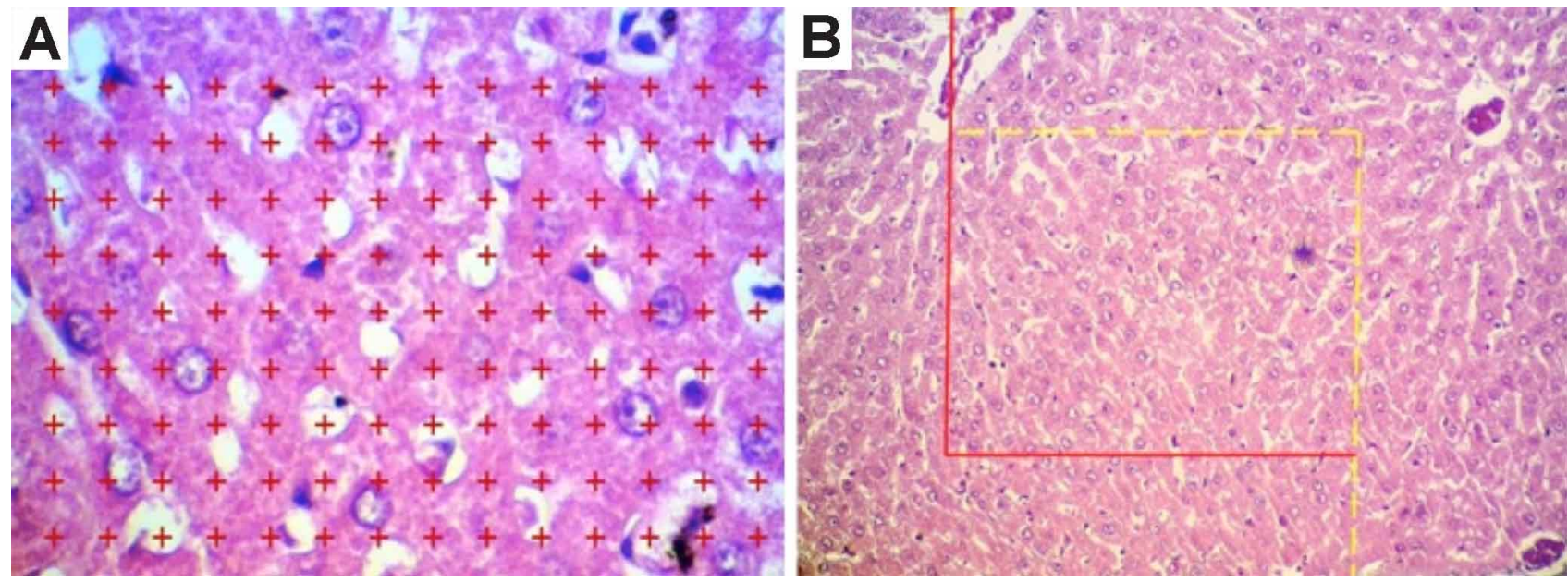

Fig. 1. A:Shows point counting method for estimating volume density usinga point probe which superimposed on the images of the tissue sections. The total number of points hitting each component was divided by the total number of the points hitting the reference space.B:Shows counting frame for estimating he length density. An unbiased counting frame with inclusion (dashed) lines and exclusion (thick) lines was superimposed on the images of the tissue sections. The tubule profiles completely inside the counting frame or partly inside the counting frame but only touching the inclusion lines are counted.

Where $\Sigma \mathrm{Q}$ is sum of the structures counted, $a$ (frame) is probe area, $313600 \mu \mathrm{m}^{2}$ and $\Sigma$ frame is total number of the counted frames (Howard \& Reed).

Statistical analysis. Statistical analysis was conducted in SPSS v. 16. The normality and homogeneity of the data were determined by the Kolmogorov-Smirnov test ( $\mathrm{P}>0.05$ ), and one-way analysis of variance (ANOVA) was utilized to compare the differences of means between groups, followed by the Tukey's post hoc test. All results were expressed as mean $\pm \mathrm{SD}$, and $\mathrm{P}<0.05$ indicated statistical significance.

\section{RESULTS}

Effects of DP extract on liver enzymes. As summarized in Table I, the serum levels of ALT, AST and ALP were

Table I. Serum biomarkers values in the control and experimental groups $(n=7)$. Results are expressed as mean \pm standard deviation.

\begin{tabular}{llll}
\hline \multicolumn{4}{c}{ Groups Liver enzymes } \\
\hline$(n=8)$ & ALT(/IU/L) & ALP(IU/L ) & AST(IU/L) \\
\hline C & $17.64 \pm 1.33^{\mathrm{c}} 18$ & $18.56 \pm 1.94^{\mathrm{b}}$ & $45.58 \pm 0.34^{\mathrm{a}}$ \\
$\mathrm{UD}$ & $53.26 \pm 0.86^{\mathrm{b}}$ & $24.39 \pm 0.87^{\mathrm{a}}$ & $133.61 \pm 0.55^{\mathrm{a}}$ \\
$\mathrm{DP} 270$ & $18.74 \pm 0.59^{\mathrm{b}}$ & $19.12 \pm 0.75^{\mathrm{b}}$ & $49.77 \pm 0.67^{\mathrm{b}}$ \\
$\mathrm{D}+\mathrm{DP} 270$ & $22.17 \pm 0.67^{\mathrm{b}}$ & $19.59 \pm 1.29^{\mathrm{b}}$ & $52.37 \pm 0.92^{\mathrm{b}}$ \\
\hline
\end{tabular}

C: control, UD: untreated diabetic, DP270: non diabetic rats treated with 270 of DP hydroalcoholic extract, D+DP270: diabetic rats treated with 270 $\mathrm{mg} / \mathrm{kg}$ of DP hydroalcoholic extract. Different superscripts in the same column indicate significant difference $(\mathrm{p} \leq 0.05)$ between groups. significantly increased $(p<0.05)$ in the diabetic group compared with the control group. This change was improved toward normal levels in the DP-treated diabetic rats. There was no significant difference $(p>0.05)$ between the DP-treated normal rats and control ones.

Effects of DP extract on antioxidant enzymes and MDA activities. The activities of antioxidant enzymes in the liver tissue including CAT, SOD, and GPX was significantly $(p<0 / 05)$ decreased in diabetic group as compared to the control group. Treatment of diabetic rats with DP extract effectively improved the activities of SOD, GPX and CAT toward normal levels. A significant $(p<0.05)$ increase of the hepatic MDA was observed in the diabetic group compared with the normal group, whereas this increment was significantly $(p<0.05)$ attenuated by the DP extract co-administration in diabetic rats (Fig. 2).

Effects of DP extract on weight and volumes of the liver and its components. The obtained data showed that the liver weight and volume as well as the total volume of the hepatocytes and sinusoids were increased significantly $(p<0.05)$ in the untreated diabetic animals in comparison with the control ones (Table II). The total volume of the central and portal veins branches were significantly $(p<0.05)$ decreased in the untreated diabetic group as compared to the control one, while the total volume of the bile duct showed significant increased $(p<$ 0.05 ) as compared to the control one. The volume of the hepatic artery branches showed insignificant difference ( $p>0.05$ ) (Table II).The total volume of the liver, 
Table II. Weight (mg) and total volume (mm3) of the liver and its structures in the control and experimental groups. Results are expressed as mean \pm standard deviation.

\begin{tabular}{|c|c|c|c|c|c|c|c|c|}
\hline \multicolumn{3}{|c|}{ Groups Weigh (mg) } & \multicolumn{6}{|c|}{ Volume $\left(\mathrm{mm}^{3}\right)$} \\
\hline$(n=8)$ & Liver & Liver & $\mathrm{Hc}$ & Sin & $\mathrm{Cv}$ & $\mathrm{Pv}$ & $\mathrm{Ha}$ & $\mathrm{Bd}$ \\
\hline $\mathrm{C}$ & $1630 \pm 102 \mathrm{a}$ & $1550 \pm 57^{\mathrm{a}}$ & $1212 \pm 49 \mathrm{a}$ & $63 \pm 9^{a}$ & $122 \pm 8^{a}$ & $42 \pm 8^{b}$ & $4.42 \pm 0.96^{\mathrm{a}}$ & $16 \pm 2.56^{\mathrm{a}}$ \\
\hline UD & $1954 \pm 836 \mathrm{c}$ & $1892 \pm 114 \mathrm{c}$ & $1674 \pm 94 \mathrm{c}$ & $101 \pm 12^{\mathrm{c}}$ & $95 \pm 17^{\mathrm{b}}$ & $28 \pm 6^{c}$ & $3.91 \pm 0.51^{\mathrm{a}}$ & $22 \pm 3.57 \mathrm{~b}$ \\
\hline DP270 & $1685 \pm 77^{\mathrm{b}}$ & $1604 \pm 89^{b}$ & $1433 \pm 37 \mathrm{~b}$ & $77 \pm 5^{b}$ & $106 \pm 5^{\mathrm{a}}$ & $51 \pm 9^{b}$ & $4.34 \pm 0.84 \mathrm{a}$ & $18 \pm 4.14 \mathrm{a}$ \\
\hline $\mathrm{D}+\mathrm{DP} 270$ & $1721 \pm 45^{\mathrm{a}}$ & $1651 \pm 63^{\mathrm{a}}$ & $1418 \pm 71 \mathrm{a}^{\mathrm{b}}$ & $69 \pm 15 a$ & $114 \pm 21 \mathrm{a}$ & $46 \pm 7^{b}$ & $4.22 \pm 0.25^{\mathrm{a}}$ & $20 \pm 5.2 \mathrm{a}$ \\
\hline
\end{tabular}

Hc; hepatocyte, Sin; sinusoid, Cv; central vein, Pv; portal vein, Ha; hepatic artery, Bd; bile duct. C: control, UD: untreated diabetic, DP270: non diabetic rats treated with 270 of DP hydroalcoholic extract, D+DP270: diabetic rats treated with $270 \mathrm{mg} / \mathrm{kg}$ of DP hydroalcoholic extract. Different superscripts in the same column indicate significant difference $(\mathrm{p} \leq 0.05)$ between groups.

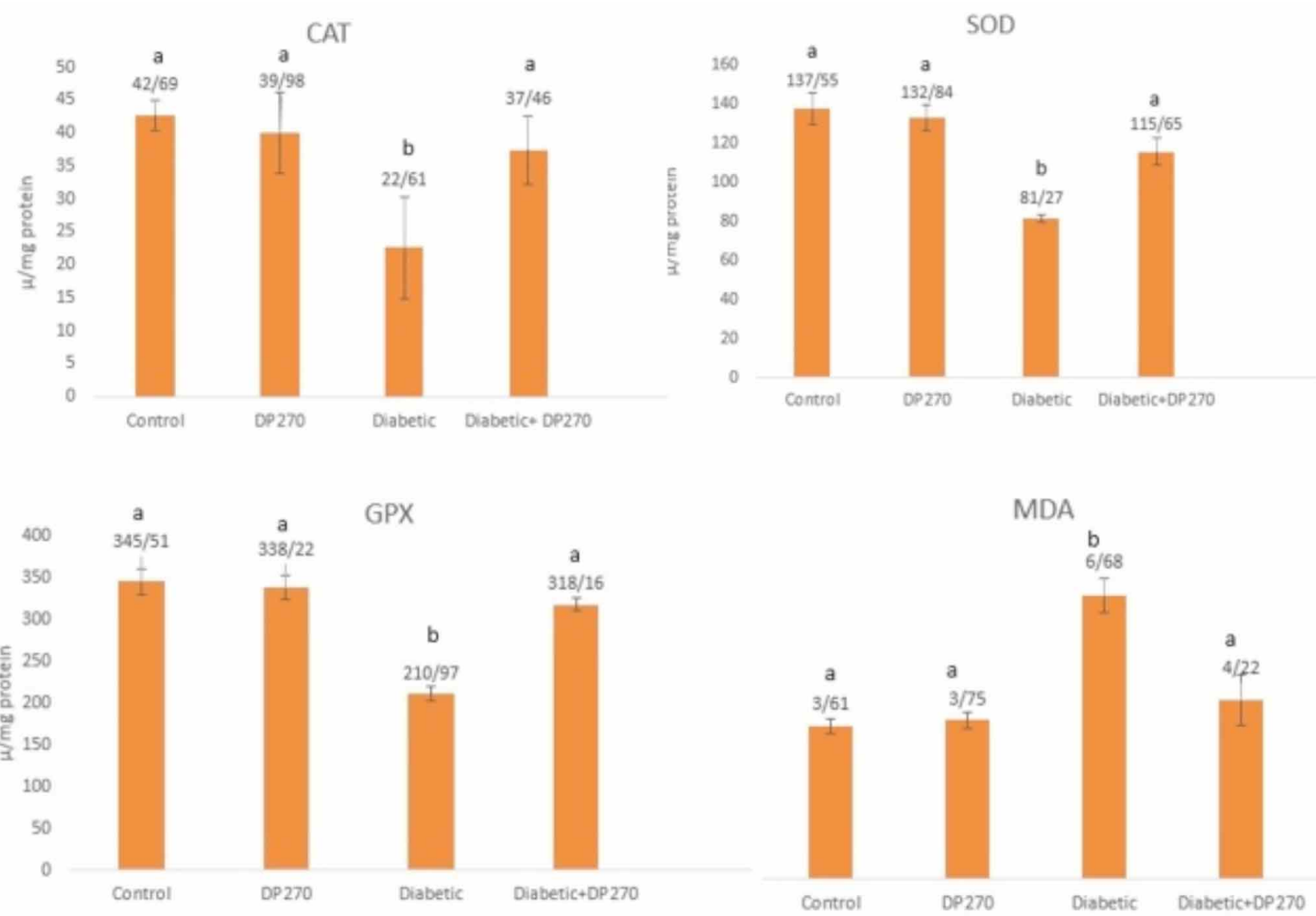

Fig. 2. Levels of the liver CAT, SOD, GPx and MDA in the control, normal group received $270 \mathrm{mg} / \mathrm{kg}$ of DP extract (DP), untreated diabetic (Diabetic) and diabetic group treated with $270 \mathrm{mg} / \mathrm{kg}$ of DP extract (Diabetic +DP270). The different letters indicate statistically significant differences. $\mathrm{p}<0.05$. $(n=8$ /group).

hepatocytes and sinusoids were significantly $(p<0.05)$ decreased in diabetic rats treated with DP extract when compared to those of the diabetic animals. The total length of the central vein, portal vein, bile duct and hepatic artery branches showed insiginificant changes $(p>0.05)$ in diabetic animals as well as in DP-treated ones (Table II and III). CE values for all stereological estimations were below $\% 5$.

Histopathological examination. Figures 3 and 4 show the histophathological changes in the liver following diabetes induction with and without the DP extract administration. The liver structure was normal in the control and DP-treated
Table III. Total length (m) the cental veins, portal veins, hepatic artery braches, and bile ducts in the control and experimental groups. Results are expressed asmean \pm standard deviation.

\begin{tabular}{|c|c|c|c|c|}
\hline \multicolumn{5}{|c|}{ Groups Total length(m) } \\
\hline$(n=8)$ & $\mathrm{Cv}$ & $\mathrm{PV}$ & $\mathrm{Ha}$ & $\mathrm{Bd}$ \\
\hline $\mathrm{C}$ & $1.27 \pm 0.18^{\mathrm{a}}$ & $1.94 \pm 0.67 \mathrm{a}$ & $0.95 \pm 0.15 \mathrm{a}$ & $0.81 \pm 0.09^{\mathrm{a}}$ \\
\hline UD & $1.05 \pm 0.15^{\mathrm{a}}$ & $1.37 \pm 0.91 \mathrm{a}$ & $0.77 \pm 0.09 \mathrm{a}$ & $0.75 \pm 0.04^{\mathrm{a}}$ \\
\hline DP270 & $1.17 \pm 0.25^{\mathrm{a}}$ & $1.75 \pm 0.66 \mathrm{a}$ & $0.85 \pm 0.06 \mathrm{a}$ & $0.92 \pm 0.1 \mathrm{a}$ \\
\hline $\mathrm{D}+\mathrm{DP} 270$ & $1.12 \pm 0.45^{\mathrm{a}}$ & $1.64 \pm 0.22 \mathrm{a}$ & $0.89 \pm 0.07 \mathrm{a}$ & $0.75 \pm 0.05^{\mathrm{a}}$ \\
\hline
\end{tabular}

$\mathrm{Cv}$; central vein, $\mathrm{Pv}$; portal vein, Ha; hepatic artery, Bd; bile duct

C: control, UD: untreated diabetic, DP270: non diabetic rats treated with 270 of DP hydroalcoholic extract, D+DP270: diabetic rats treated with 270 $\mathrm{mg} / \mathrm{kg}$ of DP hydroalcoholic extract. Different superscripts in the same column indicate significant difference $(\mathrm{p} \leq 0.05)$ between groups. 

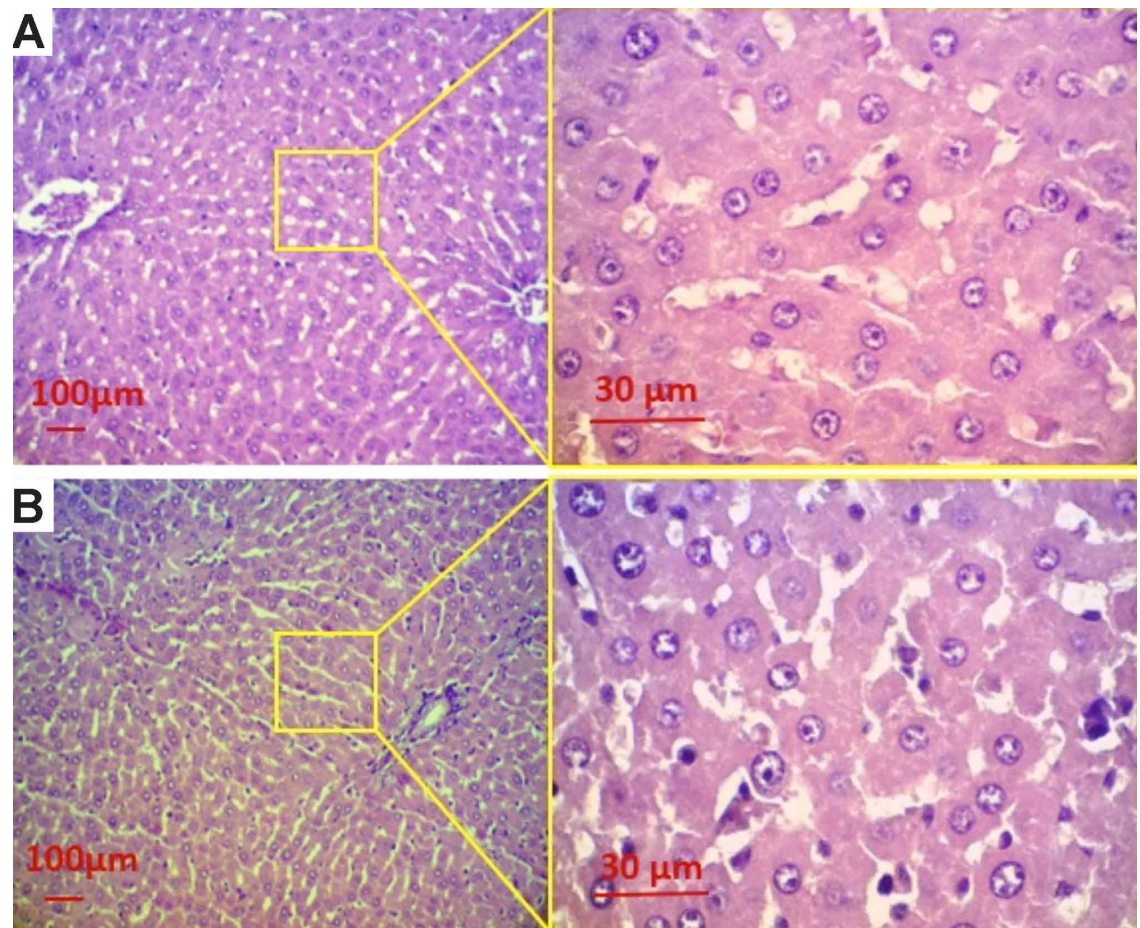

Fig. 3. Histopathological appearance of the liver sections in the control and experimental groups. A: Liver of control rats with normal structure. B: Liver section of normal rats tratd with DP extract showed normal architecture $(\mathrm{H} \& \mathrm{E}, \times 100)$. Yellow rectangles in all groups are shown at higher magnifications $(\mathrm{H} \& \mathrm{E}, \times 400)$.
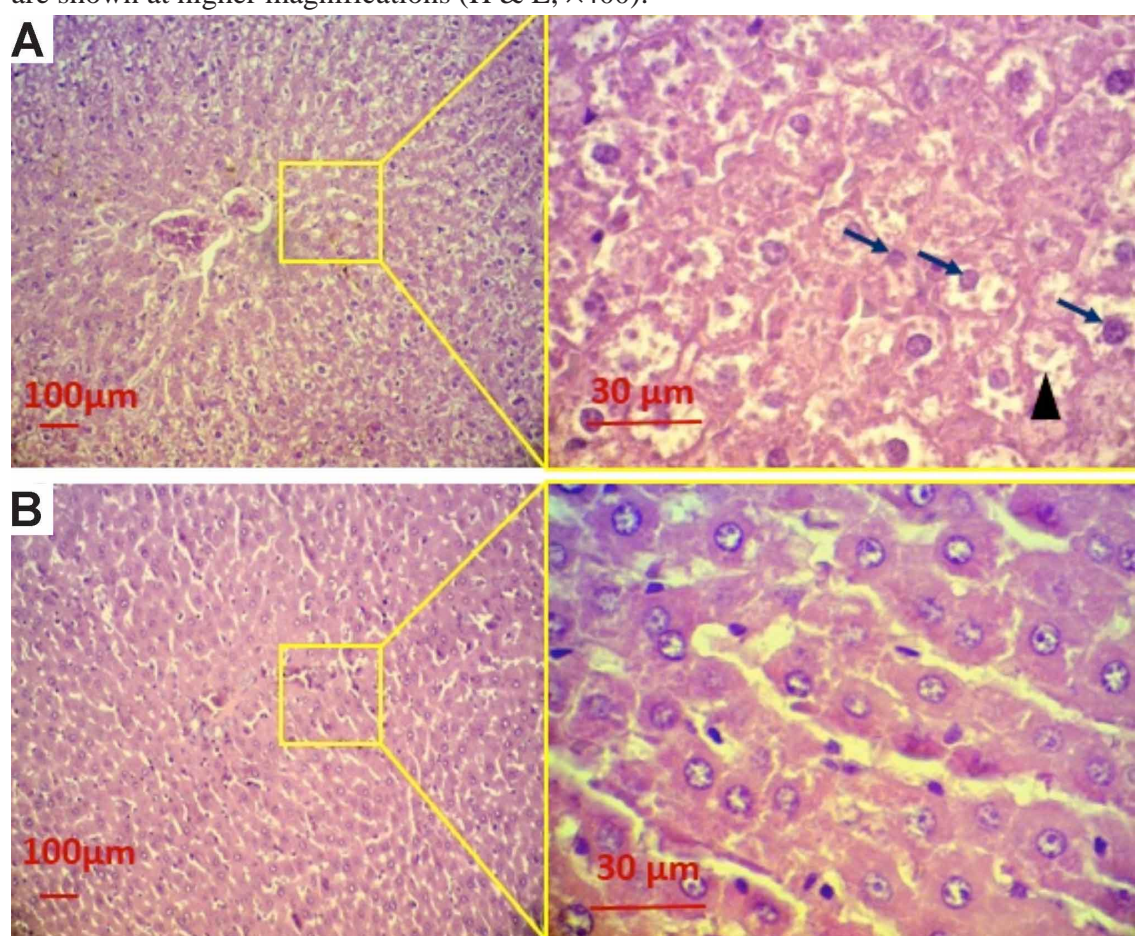

Fig. 4. A:Liver of untreated diabetic rats showed central vein congestion, necrotic nuclei (arrows) and foamy cytoplasm of hepatocytes indicated hepatosteatosis (arrowhead). B:Liver section of diabetic animals treated with $270 \mathrm{mg} / \mathrm{kg}$ of DP extract that exhibited improvement in diabetes induced histological changes toward normal appearance $(\mathrm{H} \& \mathrm{E}, \times 100)$. Yellow rectangles in all groups are shown at higher magnifications $(\mathrm{H} \& \mathrm{E}, \times 400)$. groups. Networks of healthy hepatocytes were arranged in strands around central vein. The strands of hepatocytes separated from each other by blood sinusoids, Kupffer cells were abundant in the sinusoids (Fig. 3). The diabetic group showed an extensive diabetesinduced liver injury including portal vein digestion, steatosis, necrosis-induced vacuolated hepatocytes, and inflammation. Hepatocytes showed cytoplasmic degeneration, most cells showed pyknotic and karyolysed nuclei, and some cells showed microvesicular steatosis (fatty degeneration). The liver injuries in the DP-treated diabetic group, however, are much milder, and the DP-treated normal group showed a similar condition compared with the normal group, some cells showed pyknotic nuclei and mild steatosis (Fig. 4).

Immunohistochemistry analysis. Testing of diabetic liver section for anti-acrolein gene expression showed intense bright immunofluorescent in the hepatic tissue that referred to remarkable oxidative stress. Investigating the diabetic liver sections treated with DP extract for anti-acrolein gene expression showed faintly stained immunofluorescent compared with untreated diabetic liver section, that referred to reduction in oxidative stress (Fig. 5). Measurement of optical density of immunofluorescent staining for acrolein confirmed that increased oxidative stress following STZinduced diabetes resulted in enhanced level of acrolein production in hepatocytes. The inten-sity of acrolein staining was significantly $(\mathrm{p}<0.05)$ increased in the diabetic rats as compared to the control ones. Notably, the optical density of acrolein staining was significantly $(\mathrm{p}<0.05)$ reduced in the DP-treated diabetic rats as compared to the untreated diabetic ones (Fig. 6). 

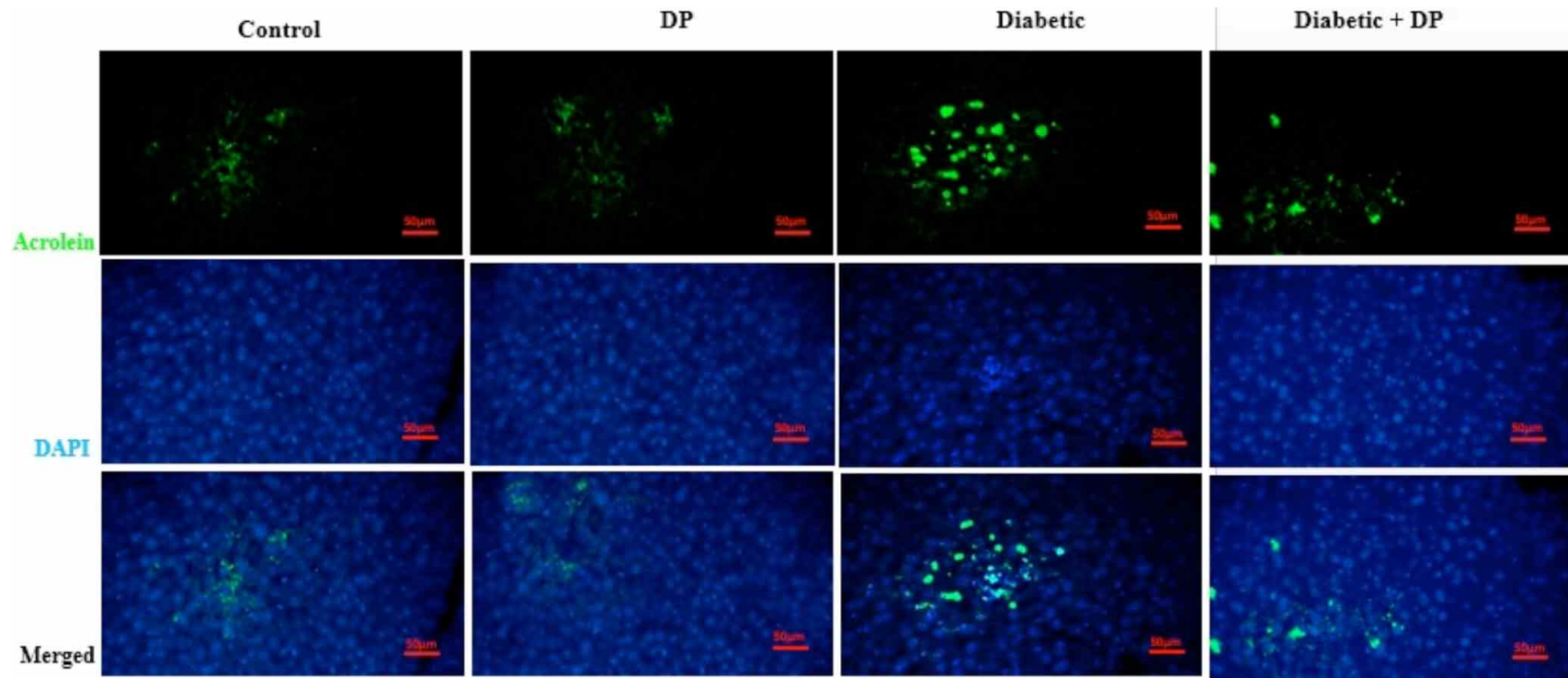

Fig. 5. Immunofluorescence detection of acrolein in the control and experimental groups. The intense immunofluorescent reactivity of anti-acroelin in the cytoplams of hepatocytes was evident in untreated diabetic rats, while it was almost negative in the control and DPtreated groups and slighter in Diabetic+DP group as compared to the untreated diabetic ones.

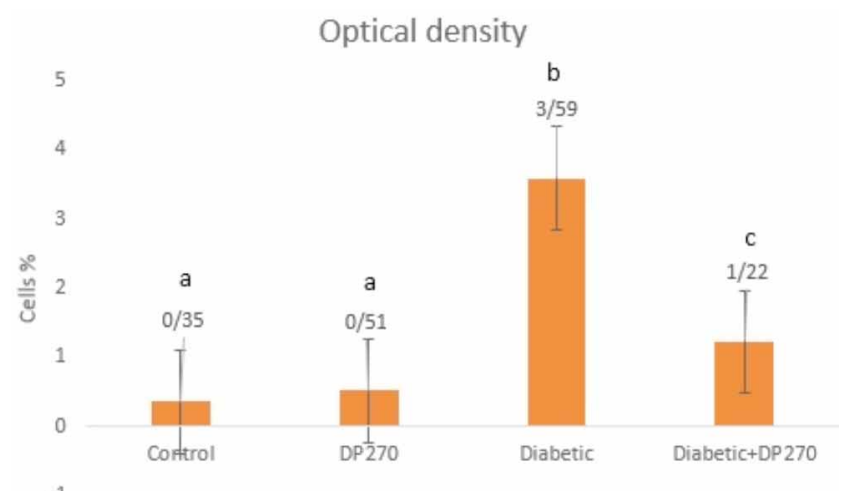

Fig. 6. Optical density of acrolein in the control, normal group received $270 \mathrm{mg} / \mathrm{kg}$ of DP extract (DP270), untreated diabetic (Diabetic) and diabetic group treated with $270 \mathrm{mg} / \mathrm{kg}$ of DP extract (Diabetic +DP270). The different letters indicate statistically significant differences. $\mathrm{p}<0.05 .(\mathrm{n}=8$ /group $)$.

\section{DISCUSSION}

Date palm has been reported as a rich source of diverse secondary metabolite possessing free radical scavenging potential that may overcome oxidative stress (Al Harthi et al., 2015). The present study was conducted to investigate the preventive effect of DP hydroalcoholic extraction against diabetes-induced hepatotoxicity in rat.

It is well established that cellular oxidative stress plays a crucially important role in diabetes-related tissue damage. Oxidative stress, a key pathogenic factor in the development of diabetic complications, induces the production of highly reactive oxygen species (ROS) that are toxic to the cell membrane in which these radicals interact with the lipid bilayer and produce lipid peroxides (Kesavulu et al., 2001; Aydin et al., 2001; Kedziora-Kornatowska et al., 2002). Despite this, the intrinsic mechanisms of this cellular aggression pathway are not fully understood.

In our study, the liver tissue of diabetic rats without any treatment showed remarkably increased production of MDA associated with reduction in the activity of antioxidant enzymes SOD, CAT and GPx. Increased oxidation of free fatty acids (FFA) by the liver can generate ROS, which can lead to lipid peroxidation processes, structural and functional alterations in cells and cell death. In physiological conditions, the organism's antioxidant defenses can neutralize the harmful effects of such substances. In pathological conditions, however, such as in diabetes, the metabolic balance is broken, and oxidative stress is initiated (Haque \& Sanyal, 2002). The maintenance of oxidative stress to the hepatic level triggers adaptation responses to chronic stress by the liver, and eventually compromise the liver's replication and regeneration capacity, leading to apoptosis or cell death. On the other hand, FFA excess in the liver may separately lead to the apoptosis of hepatocytes, thus being considered one of the cellular damage mechanisms commonly described in patients with non-alcoholic fatty liver disease (Wigget al., 2001). Although, the MDA levels were measured in the liver and its levels found to be significantly $(\mathrm{P}<0.05)$ increased in diabetic control rats, however, MDA levels was significantly lower in the DP- treated diabetic 
rats compared to the diabetic control group. This finding suggests that DP extract may protect the liver tissue from lipid peroxidation. On the other hand, the increased lipid proxidation can lead to losing the integrity of cell membrane, which later can result in release of hepatic enzymes. According to the results of hepatic enzymes measurement, the serum levels of ALT, AST and ALP showed significant elevation in the dibetic rats as compared to the control ones and reduced toward normal levels following DP extract administration.

The present study also revealed that SOD and CAT levels were decreased in the liver of diabetic rats. SOD is an important defense enzyme, which catalyses the dismutation of superoxide radicals. CAT is a hem protein that catalyses the reduction of hydrogen peroxides and protects the tissues from highly reactive hydroxyl radicals (Bolzan \& Bianchi, 2002). Therefore, reduction in the activity of these enzymes (SOD, CAT) may result in a number of deleterious effects due to the accumulation of superoxide anion radicals and hydrogen peroxide (Aragno et al., 1997). These antioxidant enzymes SOD and CAT levels significantly increased after the treatment of DP extract in STZ-induced diabetic rats indicating its free radical scavenging activity and protective effect against cellular damage. These findings on the antioxidant effects and scavenging activity of DP extract are consistent with the reports of other researchers. Hosseinipour et al. investigated the effect of DP extract on diabetesinduced testicular toxicity and revealed that this extract probably improves testicular injuries in diabetic rats via its antioxidant and anti-apoptotic properties rather than its direct effect on hypothalamus-hypophysis-gonad axis. Based on the previous reports, several antioxidant compounds were identified in the date palm. 9-Octadecenoic acid (Z), methyl ester and Dodecanoic acid known as Methyl oleate and Methyl laurate, Gallic acid and Oleic acid were the most compound found in the date palm. The antioxidant potential of these compounds were previously approved (Biglari et al., 2008; Siahpoosh et al., 2011; Al-Harthi et al., 2015; Nehdi et al., 2018).

Studies have revealed the prominent histopathological changes in the livers of diabetic patients.

The main pathological change is steatohepatitis that can be diagnosed by the presence of hepatocellular steatosis, lobular inflammation and varying degrees of pericellular, perisinusoidal and periportal fibrosis including cirrhosis. Other dominant features of steatohepatitis besides glycogenated nuclei are hepatocyte ballooning, varying degrees of hepatocyte necrosis. Degenerative changes are characterized by the vacuolation of hepatocytes in the centrizonal area of the cell and a discrepancy in the size of the nuclear and dilated sinusoidal spaces (Stefan et al., 2014). As our observation revealed, the hepatic tissue of uutreated diabetic rats showed degenerative changes, vacuolated cytoplasm, pyknotic and karyolysed nuclei, and fatty degeneration. Furthermore, quantitative analysis of the liver showed remarkable increase in the volume of the hepatocytes and sinusoids which can be due to the inflammatory process induced by diabetes. In the DP-treated diabetic rats, however, these structural changes were milder and indicated that DP extract could protects the liver structure from diabetesinduced injuries.

In the present work, the production of acrolein was investigated through immunofluorescence staining. Acrolein is a highly reactive ubiquitous pollutant in the environment that is generated oxidative stress endogenously (Mohammad et al., 2012). Notably, acrolein can be formed via lipid proxidation in various pathological conditions including renal failure (Sakata et al., 2003) brain infarction (Saiki et al., 2011) and spinal cord injuries (Hamann et al., 2008). Due to its solubility in water, acrolein can easily move across cell membranes. Thus, high concentrations of acrolein are produced by oxidative stress, and can spread from the dying cells to damage and kill adjacent cells and tissues. Although it has been widely hypothesized that the major factor responsible for cell damage under oxidative stress conditions is ROS, it now appears that acrolein, a as byproduct of oxidative stress, is more toxic than ROS and promotes secondary injury in various tissue (Arai et al., 2014). Our observations revealed that acrolein was more strongly positive in untreated diabetic rats as compared to those diabetic rats treated with DP extract. While it was not evident in the normal control ones. This finding is in consistent with the previous reports that demonstrated acrolein-mediated pathogenesis in diabetes (Daimon et al., 2003; Aldahmash et al., 2016) and indicated that acrolein can contributed to proceed diabetes complications. Therefore, supplements with antioxidant properties can be used to inhibit acrolein genesis and aggravation of diseases that have implicated acrolein in their pathogenesis such as renal failure (Sakata et al.), diabetes (Daimon et al.), atherosclerosis (Uchida et al., 1998) and Parkinson's disease (Shamoto-Nagai et al., 2007).

\section{CONCLUSION}

The present data suggest that date palm hydroalcoholic extract can be effective to protect the liver's function and structure following STZ-induced diabetes. It is evident that protective effect of date palm and other medicinal plants is related to their natural antioxidant compounds. Therefore, antioxidant therapy is a potential 
future therapeutic strategy that enhance antioxidant levels in diabetic patients with induced liver injury and dysfunction may hopefully counter the effects of oxidative stress and inflammation, thereby reducing the severity of diabetic complications.

\section{ACKNOWLEDGMENTS}

The authors extend their appreciation to the Deanship of Scientific Research at King Khalid University, Abha, KSA for their financial supports.

FUNDING. This research was funded by the deanship of Scientific Research at King Khalid University, Abha, KSA, under grant number R.G.P.2/80/41.

ZHENG, Y.; EL-KOTT, A. F.; SHALDOUM, F.; MASSOUD, D.; PAN, Y. \& ELBEALY, E. R. Alivio de la hepatotoxicidad inducida por diabetes mediante el extracto hidroalcohólico de palmera datilera en modelo de rata; un estudio bioquímico, inmunohistoquímico y estereológico. Int. J. Morphol., 39(3):876-885, 2021.

RESUMEN: El presente estudio tuvo como objetivo investigar los efectos hepatoprotectores del extracto hidroalcohólico (DP) de la palmera datilera en ratas diabéticas utilizando enfoques bioquímicos e histopatológicos. La diabetes fue inducida mediante la administración de $60 \mathrm{mg} / \mathrm{kg}$ de estreptozotocina por vía intraperitoneal. Se dividieron al azar 32 ratas adultas en cuatro grupos; grupo 1: control no diabético que recibió $0,1 \mathrm{~mL}$ de solución salina normal, grupo 2: control no diabético tratado con $270 \mathrm{mg} / \mathrm{kg}$ de DP, grupo 3: fue separado como diabético no tratado, y grupo 4: ratas diabéticas tratadas con $270 \mathrm{mg} / \mathrm{kg}$ de DP mg / kg de DP. Las ratas diabéticas tratadas con los extractos de DP mostraron menor estrés oxidativo hepático y menor nivel de enzimas hepáticas. El tratamiento con extracto disminuyó el nivel de malondealdehído (MDA) como marcador de la proxidación de lípidos. Las estimaciones estereológicas revelaron un aumento significativo en el volumen del hígado en ratas diabéticas que se redujo en las ratas tratadas con DP. La tinción por inmunofluorescencia mostró una alta síntesis de acroleína como subproducto de la proxidación de lípidos. Mientras que, la medición de la densidad óptica reveló una disminución significativa de la acroleína después de la administración de DP. El examen histopatológico mostró cambios significativos en el tejido hepático diabético no tratado manifestados por vena porta dilatada, infiltración leucocítica, degeneración grasa y núcleos necróticos, mientras que el tratamiento con DP atenuó los efectos adversos de la diabetes en el hígado representados por hepatocitos y sinusoides relativamente sanos. Los resultados obtenidos indicaron que el extracto de palmera datilera fue beneficioso en la prevención de la hepatotoxicidad inducida por diabetes debido a sus constituyentes antioxidantes naturales. Se necesitan más estudios clínicos para considerar esta planta en el manejo de la prediabetes y las complicaciones hepáticas de la diabetes.

PALABRAS CLAVE: Palmera datilera; Diabetes; Acroleína; Antioxidante; Hepatoprotección.

\section{REFERENCES}

Al-Alawi, A.; Al-Mashiqri, R. A.; Al-Nadabi, J. H. \& Met, J. S. Date palm tree (Phoenix dactylifera $\mathrm{L}$.): natural products and therapeutic options. Front. Plant. Sci., 8:1-12, 2017.

Aldahmash, B. A.; El-Nagar, D. M. \& Elfakki, I. K. Attenuation of hepatotoxicity and oxidative stress in diabetes STZ-induced type 1 by biotin in Swiss albino mice. Saudi J. Biol. Sci., 23:311-7, 2016.

Al Harthi, S. S.; Mavazhe, A. \& Al Mahroqi, H. Quantification of phenolic compounds, evaluation of physicochemical properties and antioxidant activity of four date (Phoenix dactylifera L.) varieties of Oman. $J$. Taibah Univ. Sci., 10(3):346-52, 2015.

Andreoli, T. E.; Carpenter, C. C: J.; Griggs, R. \& Benjamin, I. Diseases of the Liver and Biliary System. In: Andreoli, T. E.; Carpenter, C. C. J. \& La Fayette Cecil, R. Cecil's Essentials of Medicine. 7th ed. Philadelphia, Saunders, 2007.

Aragno, M.; Brignardello, E. \& Tamagno E. Dehydroepiandrosterone administration prevents the oxidative damage induced by acute hyperglycemia in rats. J. Endocrinol., 155:233-40, 1997.

Arai, T.; Koyama, R.; Yuasa, M. Acrolein, a highly toxic aldehyde generated under oxidative stress in vivo, aggravates the mouse liver damage after acetaminophen overdose. Biomed. Res., 35(6):389-95, 2014.

Aydin, A.; Orhan, H. \& Sayal, A. Oxidative stress and nitric oxide related parameters in type II diabetes mellitus: effects of glycemic control. Clin. Biochem., 34:65-70, 2001.

Biglari, F.; AlKarkhi, A. F. M. \& Easa, A. M. Antioxidant activity and phenolic content of various date palm (Phoenix dactylifera) fruits from Iran. Food. Chem., 107:1636-41, 2008.

Bolzan, A. D. \& Bianchi, M. S. Genotoxicity of streptozotocin. Mutat. Res., 512:121-34, 2002.

Canadian Diabetes Association Clinical Practice Guidelines Expert Committee; McFarlane, P.; Gilbert, R. E.; MacCallum, L. \& Senior, P. Chronic kidney disease in diabetes. Can. J. Diabetes, 37 Suppl. 1:S129-36, 2013

Chaira, N.; Smaali, M. I. \& Martinez-Tomé, M. Simple phenolic composition, flavonoid contents and antioxidant capacities in watermethanol extracts of Tunisian common date cultivars (Phoenix dactylifera L.). Int. J. Food Sci. Nutr., 60(Suppl. 7):316-29, 2009.

Daimon, M.; Sugiyama, K. \& Kameda W. Increased urinary levels of pentosidine, pyrraline and acrolein adduct in type 2 diabetes. Endocr. J., 50:61-7, 2003

Gupta, S.; Kataria, M.; Gupta, P. K.; Murganandan, S. \& Yashroy, R. C. Protective role of extractsof neem seeds in diabetes caused by Streptozotocin in rats. J. Ethnopharmacol., 90:185-9, 2004.

Hamann, K.; Durkes, A. \& Ouyang, H. Critical role of acrolein in secondary injury following ex vivo spinal cord trauma. J. Neurochem., 107:71221, 2008.

Han, D.; Hanawa, N.; Saberi, B. \& Kaplowitz, N. Mechanisms of liver injury: III - Role of glutathione redox status in liver injury. Am. $J$. Physiol. Gastrointest. Liver. Physiol., 291:1-7, 2006.

Haque, M. \& Sanyal, A. J. The metabolic abnormalities associated with non-alcoholic fatty liver disease. Best Pract. Res. Clin. Gastroenterol., 16:709-31, 2002.

Ho, Y. S.; Magnenat, J. L. \& Bronsoni, R. T. Mice deficient in cellular glutathione peroxidase develop normally and show no increased sensitivity to hyperoxia. J. Biol. Chem., 272(26):16644-51, 1997.

Hosseinipour, M.; Goodarzi, N. \& Bakhtiari, M. Protective efficiency of Ashrasi date palm hydroalcoholic extract against diabetes-induced testicular toxicity: A biochemical and stereological study. Andrologia., 51(11):e13420, 2019.

Howard, V. \& Reed, M. G. Unbiased stereology: three-dimensional measurement in microscopy. New York, Garland Science/BIOS Scientific, 2005. pp. 158. 
Kedziora-Kornatowska, K.; Szram, S.; Kornatowski, T.; SzadujkisSzadurski, L.; Kedziora, J. \& Bartosz, G. The effect of verapamil on the antioxidant defence system indiabetic kidney. Clin. Chim. Acta, 322(1-2):105-12, 2002.

Kesavulu, M. M.; Rao, B. K. \& Giri, R. Lipid peroxidation and antioxidant enzyme status in Type 2 diabetics with coronary heart disease. Diabetes Res. Clin. Pract., 53:33-9, 2001.

Kitabchi, A. E.; Umpierrez, G. E.; Miles, J. M. \& Fisher, J. N. Hyperglycemic crises in adult patients with diabetes. Diabetes Care., 32(7):1335-43, 2009.

Leung, T. M. \& Nieto, N. CYP2E1 and oxidant stress in alcoholic and nonalcoholic fatty liver disease. J. Hepatol., 58:395-8, 2013.

Lukacínová, A.; Mojzis, J.; Benacka, R.; Keller, J.; Maguth, T. \& Kurila, P. Preventive effects of flavonoids on alloxan-induced diabetes mellitus in rats. Acta Vet. Brno, 77(2):175-82, 2008.

Manna, P.; Das, J.; Ghosh, J. \& Sil, P.C. Contribution of type 1 diabetes to rat liver dysfunction and cellular damage via activation of NOS, PARP, IkappaBalpha/NF-kappaB, MAPKs, and mitochondria-dependent pathways: Prophylactic role of arjunolic acid. Free Radic. Biol. Med., 48(11):1465-84, 2010.

Mantovani, A.; Byrne, C. D.; Bonora, E. \& Targher, G. Nonalcoholic fatty liver disease and risk of incident type 2 diabetes: a meta-analysis. Diabetes Care., 41(2):372-82, 2018.

Martin, J. P.; Dailey, M. \& Sugarman, E. Negative and positive assays of superoxide dismutase based on hematoxylin autoxidation. Arch. Biochem. Biophys., 255(2):329-36, 1987.

McPherson, S.; Hardy, T.; Henderson, E.; Burt, A. D.; Day, C. P. \& Anstee, Q. M. Evidence of NAFLD progression from steatosis to fibrosingsteatohepatitis using paired biopsies: implications for prognosis and clinical management. J. Hepatol., 62(5):1148-55, 2015.

Mohammad, M. K.; Avila, D.; Zhang, J.; Barve, S.; Arteel, G.; McClain, C. \& Joshi-Barve, S. Acrolein cytotoxicity in hepatocytes involves endoplasmic reticulum stress, mitochondrial dysfunction and oxidative stress. Toxicol. Appl. Pharmacol., 265(1):73-82, 2012.

Nehdi, I. A.; Sbihi, H. M.; Tan, C. P.; Rashid, U. \& Al-Resayes, S. I. Chemical Composition of Date Palm (Phoenix dactylifera L.) Seed Oil from Six Saudi Arabian Cultivars. J. Food Sci., 83(3):624-30, 2018.

Nyengaard, J. R. Stereologic methods and, their application in kidney research. J. Am. Soc. Nephrol., 10(5):1100-23, 1990.

Pakul, J. \& Leszczyns, D. E. Butylated hydroxytoluene addition improves the thiobarbituric acid assay for malonaldehyde from chicken plasma fat. Mol. Nutr. Food Res., 30(7):673-9, 1986.

Palsamy, P.; Sivakumar, S. \& Subramanian, S. Resveratrol attenuates hyperglycemia-mediated oxidative stress, proinflammatory cytokines and protects hepatocytes ultrastructure instreptozotocin-nicotinamideinduced experimental diabetic rats. Chem. Biol. Interact., 186(2):20010, 2010.

Parveen, K.; Khan, M. R.; Mujeeb, M. \& Siddigui, W. A. Protective effects of Pycnogenol on hyperglycemia-induced oxidative damage in the liver of type 2 diabetic rats. Chem. Biol. Interact., 186(2):219-27, 2010.

Placer, Z. A.; Cushman, L. L. \& Johnson, B C. Estimation of product of lipid peroxidation (malonyl dialdehyde) in biochemical systems. Anal. Biochem., 16(2):359-64,1966.

Raayati Jahromi, A.; Rasooli, R.; Kamali, Y.; Ahmadi, N. \& Sattari, E. Short-term effects of date palm extract (Phoenix dactylifera) on ischemia/reperfusion injury induced by testicular torsion/detorsion in rats. Pharmacognosy Res., 9(1):69-73, 2017.

Rahmani, A. H.; Aly, S. M.; Ali, H.; Babiker, A. Y.; Srikar, S. \& Khan, A. A. Therapeutic effects of date fruits (Phoenix dactylifera) in the prevention of diseases via modulation of anti-inflammatory, anti-oxidant and anti-tumour activity. Int. J. Clin. Exp. Med., 7(3):483-91, 2014.

Saiki, R., Park, H.; Ishii, I.; Yoshida, M.; Nishimura, K.; Toida, T.; Tatsukawa, H.; Kojima, S.; Ikeguchi, Y.; Pegg, A. E.; et al. Brain infarction correlates more closely with acrolein than with reactive oxygen species. Biochem. Biophys. Res. Commun., 404(4):1044-9, 2011.
Sakata, K.; Kashiwagi, K.; Sharmin, S.; Ueda, S.; Irie, Y.; Murotani, N. \& Igarashi, K. Increase in putrescine, amine oxidase, and acrolein in plasma of renal failure patients. Biochem. Biophys. Res. Commun., 305(1):143-9, 2003.

Scherle, W. A simple method for volumetry of organs in quantitative stereology. Mikroskopie, 26(1):57-60, 1970.

Shamoto-Nagai, M.; Maruyama, W.; Hashizume. Y.; Yoshida, M.; Osawa, T.; Riederer, P. \& Naoi, M. In parkinsonian substantia nigra, alphasynuclein is modified by acrolein, a lipid-peroxidation product, and accumulates in the dopamine neurons with inhibition of proteasome activity. J. Neural. Transm. (Vienna), 114(12):1559-67, 2007.

Shimoda, H.; Tanaka, J.; Kikuchi, M.; Fukuda, T.; Ito, H.; Hatano, T. \& Yoshida, T. Effect of polyphenol-rich extract from walnut on dietinduced hypertriglyceridemia in mice via enhancement of fatty acid oxidation in the liver. J. Agric. Food Chem., 57(5):1786-92, 2009.

Siahpoosh, A.; Gol Fakhrabadi, F. \& Jorkesh, F. Determination and comparison of antioxidant activity of aqueous and methanol extracts of date palm (Phoenix dactylifera L.var dayri). Res. Med., 35(2):68$81,2011$.

Stefan, N.; Sun, Q.; Fritsche, A.; Machann, J.; Schick, F.; Gerst, F.; Jeppesen, C.; Joost, H. G.; Hu, F. B.; Boeing, H.; et al. Impact of the adipokine adiponectin and the hepatokine fetuin-A on the development of type 2 diabetes: Prospective cohort- and cross-sectional phenotyping studies. PLoS One, 9:e92238, 2014.

Sung, K. C.; Seo, D. C.; Lee, S. J.; Lee, M. Y.; Wild, S. H. \& Byrne, C. D. Non alcoholic fatty liver disease and risk of incident diabetes in subjects who are not obese. Nutr. Metab. Cardiovasc. Dis., 29(5):489-95, 2019.

Uchida, K.; Kanematsu, M.; Sakai, K.; Matsuda, T.; Hattori, N.; Mizuno, Y.; Suzuki, D.; Miyata, T.; Noguchi, N.; Niki, E.; et al. Protein-bound acrolein: potential markers for oxidative stress. Proc. Natl. Acad. Sci. U. S. A., 95(9):4882-7,1998.

Vayalil, P. K. Antioxidant and antimutagenic properties of aqueous extract of date fruit (Phoenix dactylifera L. Arecaceae). J. Agric. Food Chem., 50(3):610-7, 2002.

Vijaya Bharathi, B.; Jaya Prakash, G.; Krishna, K. M.; Ravi Krishna, C. H.; Sivanarayana, T.; Madan, K.; Rama Raju, G. A. \& Annapurna, A. Protective effect of alpha glucosyl hesperidin (G-hesperidin) on chronic vanadium induced testicular toxicity and sperm nuclear DNA damage in male Sprague Dawley rats. Andrologia, 47(5):568-78, 2015.

Wei, Y.; Chen, P.; de Bruyn, M.; Zhang, W.; Bremer, E. \& Helfrich, W. Carbon monoxide-releasing molecule-2 (CORM-2) attenuates acute hepatic ischemia reperfusion injury in rats. BMC Gastroenterol., 10:42, 2010.

Welt, K.; Weiss, J.; Martin, R.; Dettmer, D.; Hermsdorf, T.; Asayama, K.; Meister, S. \& Fitzl, G. Ultrastructural, immunohistochemical and biochemical investigations of the rat liver exposed to experimental diabetes und acute hypoxia with and without application of Ginkgo extract. Exp. Toxicol. Pathol., 55(5):331-45, 2004.

Wigg, A. J.; Roberts-Thomson, I. C.; Dymock, R. B.; McCarthy, P. J.; Grose, R. H. \& Cummins, A. G. The role of small intestinal bacterial overgrowth, intestinal permeability, endotoxaemia, and tumour necrosis factor alpha in the pathogenesis of non-alcoholic steatohepatitis. Gut, 48(2):206-11, 2001.

\section{Corresponding author: \\ Yan Pan}

Department of Burn and Plastic Surgery

Xi'an Central Hospital, № 161

Xiwu Road, Xi'an City

Shaanxi Province, 710003

CHINA

E-mail: panyan2398612179@sina.com

Received: 23-12-2020 Accepted: 05-02-2021 